\title{
THE INFLUENCE OF THE CREATIVE KAMPONG'S TOURIST ACTIVITIES ON THE CHANGE IN LAY-OUT FOR ACTIVITIES AND THE CHANGE IN SPATIAL ARRANGEMENT OF THE DAGO POJOK KAMPONG IN BANDUNG
}

\author{
${ }^{1}$ Maria Kencana Hanggana Raras. ${ }^{2}$ Dr. Giosia Pele Widjaja, S.T., M.T. \\ ${ }^{1}$ Student in the Bachelor's (S-1) Study Program in Architecture \\ at Parahyangan Catholic University \\ ${ }^{2}$ Senior lecturer in the Bachelor's (S-1) Study Program in Architecture \\ at Parahyangan Catholic University
}

\begin{abstract}
Bandung the Champ" is a program organized by Bandung's Municipal Government to develop the local economy and increase the quality of urban life. One of these programs is called the Kampong Champ, which puts forward the concept of the Creative Kampong. The purpose of this program is to develop the economy of the local community by way of exploring the potential of the citizens, and to create a kampong fit for tourism. The Creative Kampong at Dago Pojok has been built and expanded from 2010 up to the present. The phenomenon that has taken place consists of the change made in the spatial lay-out to accommodate tourist activities based in these quarters that are of a temporary kind.

This research project aims to identify the change mentioned above as a consequence of the marked shift from daily activities in the neighborhood to tourism-related ones and to reveal the influence of the change in spatial arrangement made in this kampong on the spatial lay-out of the Dago Pojok area. The methods employed for this research consist of the qualitative method and the descriptive method along with field observation using the technique of observing place-centered mapping.

The study of the discussion starts off with identifying the arrangement of physical space that has undergone change due to a change in activity, followed by an analysis of the influence of the architectural elements on the change made in the lay-out of physical space and the approach to the morphological aspects of the city to identify the impact of these changes on the planning of this urban area.

The results of the study indicate that the changes made in the arrangement of the activity space and the circulation have been caused by the change in daily activities into tourism-related ones coming from the Creative Kampong so that the latter's spatial lay-out cannot accommodate these activities properly.

As a consequence, the space needs to be rearranged with the element of semi-fixed features due to the density of the relatively tall buildings in this urban kampong. The changes in spatial arrangement made in the various areas under observation have exerted an influence on the urban kampong's spatial lay-out, amounting to a structural change in the lay-out and orientation as well as the formation of hierarchy and datum in the area of Dago Pojok.
\end{abstract}

Keywords : Tourism, Creative Kampong, change in lay-out, change in spatial arrangement

\section{PENGARUH KEGIATAN WISATA KAMPUNG KREATIF TERHADAP PENGUBAHAN TATAAN RUANG KEGIATAN DAN PERUBAHAN TATANAN SPASIAL KAMPUNG DAGO POJOK - BANDUNG}

\author{
${ }^{1}$ Maria Kencana Hanggana Raras. ${ }^{2}$ Dr. Giosia Pele Widjaja, S.T., M.T. \\ ${ }^{1}$ Mahasiswa S1 Program Studi Arsitektur Universitas Katolik Parahyangan. \\ ${ }^{2}$ Dosen Pembimbing S1 Program Studi Arsitektur Universitas Katolik Parahyangan.
}

\begin{abstract}
Abstrak- Bandung Juara merupakan program pemerintah kota Bandung untuk membangun perekonomian dan peningkatan kualitas kota, salah satu programnya adalah Kampung Juara yang mengedepankan konsep
\end{abstract}

\footnotetext{
${ }^{1}$ Corresponding Author: maria.kencana@ymail.com
} 
Kampung Kreatif . Tujuan Program Kampung Kreatif adalah membangun perekonomian masyarakat sekitar melalui penggalian potensi warga dan menciptakan kampung wisata. Kampung Kreatif Dago Pojok merupakan kampung kreatif yang dibangun pada tahun 2010 hingga saat kini. Fenomena yang terjadi pada Kampung Kreatif adalah adanya pengubahan tataan ruang untuk mewadahi kegiatan wisata kampung kreatif yang bersifat temporer.

Penelitian bertujuan untuk mengidentifikasi pengubahan tataan ruang akibat perubahan kegiatan sehari-hari menjadi kegiatan wisata kampung serta mengidentifikasi pengaruh pengubahan tataan ruang kegiatan wisata kampung terhadap tatanan spasial kawasan Dago Pojok.

Metode yang digunakan adalah metode kualitatif serta metode deskriptif, dan juga observasi lapangan dengan teknik pengamatan place centered mapping. Kajian pembahasan diawali dengan identifikasi tatanan ruang fisik yang mengalami pengubahan akibat perubahan kegiatan, analisa mengenai pengaruh elemen arsitektural terhadap pengubahan tataan ruang fisik dan pendekatan terhadap aspek morfologi kota untuk mengidentifikasi pengaruh pengubahan terhadap tatanan kawasan.

Hasil studi menunjukkan bahwa pengubahan tataan ruang kegiatan dan sirkulasi disebabkan oleh pengubahan kegiatan sehari - hari menjadi kegiatan wisata dari kampung kreatif, sehingga tatanan ruang dari kampung tersebut tidak mampu mewadahi kegiatan dengan baik. Sehingga terjadi penataan ulang dengan elemen semifixed feature akibat kerapatan bangunan yang relatif tinggi pada kampung kota. Pengubahan tataan ruang pada beberapa area amatan mempengaruhi tatanan spasial kampung kota, terjadi adanya perubahan struktur tata ruang dan orientasi serta pembentukan hirarki dan datum pada kawasan Dago Pojok.

Kata-kata kunci : wisata kampung kreatif, pengubahan tataan ruang, perubahan tatanan spasial

\section{PENDAHULUAN}

\subsection{LATAR BELAKANG PENELITIAN}

Kepadatan jumlah penduduk di Bandung semakin tinggi, tercatat dalam mencapai 14.228 jiwa per kilo meter (Badan Pusat Statistik Jabar, 2014).Kepadatan penduduk tidak diikuti dengan pertambahan area untuk pemukiman warga, terutama pada wilayah perkotaan. Perkampungan kota merupakan pemukiman perkotaan akibat adanya urban pocket dan pembangunan tidak terencana. Pengembangan program Inovasi Pembangunan dan Kewilayahan Kota Bandung merupakan hal utama yang direncanakan untuk meningkatkan kualitas hidup warga Bandung. Program tersebut dikenal dengan sebutan Bandung Juara, merupakan program peningkatan etos kerja yang disuarakan Ridwan Kamil sejak terpilihnya beliau pada tahun 2013 sebagai walikota Bandung. Visi Bandung juara adalah mewujudkan kota Bandung yang Nyaman, Unggul dan Sejahtera.

Sesuai dengan visi Bandung Juara, maka diterbitkan Intruksi Walikota Bandung No. 02 tahun 2013 tentang Aksi Menuju Bandung Juara, dalam intruksi ke 4, alinea 1e meliputi Kampung Juara sebagai salah satu elemen pendukung untuk mencapai tujuan menjadi Bandung Juara. Kampung Juara merupakan konsep merevitalisasi kampung dengan mengubah pola pikir warga kampung, meningkatkan etos kerja, pembangunan ekonomi kreatif yang mandiri serta perbaikan kualitas lingkungan kampung. Tujuan dari Kampung Juara ini adalah untuk meningkatkan perkenomian masyarakat baik dari segi penciptaan produk lokal maupun dari sektor pembangunan pariwisata di kampung tersebut.

Upaya mewudujkan Kampung Juara, maka dibentuklah Kampung Kreatif, memiliki konsep arsitektur humanis dan menggunggulkan 1 produk tertentu yang diproduksi secara masal, mulai dari kreatifitas dalam bidang seni mural, karawitan hingga kreatif dalam hal memproduksi produk khas kampung tersebut. Konsep Kampung kreatif diadopsi dari konsep OVOP (One Village One Product) oleh Morhiko Hiramatsu, gubernur Perfektur Oita. Tujuan dari OVOP adalah mengembangkan produk yang mampu bersaing dipasar global dengan tetap menekankan pada nilai tambah lokal dan mendorong semangat menciptakan kemandirian masyarakat. Pada tahun 2008 konsep ini mulai diterapkan diberbagai negara di Asia, termasuk di Indonesia Dalam kurun waktu 3 tahun dari pemerintahan Ridwan Kamil, 
terdapat 7 Kampung yang diresmikan sebagai kampung kreatif, diantaranya adalah Kampung Akustik Cicadas, Kampung Lokomotif Cikukang, Kampung Blekok, Kampung Kreatif Pasundan, Kampung Langitan Leuwianyar dan Kampung Dago Pojok. Namun Penelitian difokuskan pada satu objek kampong, yaitu Kampung Dago Pojok. Pemilihan Kampung Dago Pojok disebabkan kampug tersebut merupakan kampung yang sukses menerapkan konsep OVOP hingga saat kini, sebagai indicator dari kesuksesan Kampung Dago Pojok, adalah peresmian Kampung bukan hanya sebagai kampung kreatif, namun telah diresmikan sebagai Kampung wisata kreatif sejak 28 Oktober 2011.

Kampung Dago Pojok mulai aktif menjadi Kampung Kreatif sejak tahun 2010. Awal terjadinya gerakan kreatif, berawal dari adanya komunitas Taboo, yaitu komunitas rumah baca yang mewadahi anak-anak putus sekolah di kampung tersebut.Pada awalnya hanya sekedar rumah baca, kemudian berkembang menjadi sanggar atau workshop pelatihan melukis. Pada tahun 1960 sampai 1980, kampung ini dihuni oleh pelaku kesenian, seperti dalang dan pengrajin alat musik seni karawitan. Namun menjelang tahun 1990 sampai tahun 2000, sebagian besar penghuni kampung beralih profesi sebagai buruh bangunan dan mengubah rumahnya menjadi kos-kosan, di era itulah pengubahan kampung ini semakin buruk. Banyak tidakan kriminal yang berasal dari pendatang dan sikap individualism. Namun pada tahun 2010 Bapak Rahmat Jabaril (pendiri komunitas taboo) melihat potensi pada kampung berada pada jalur seni. Melihat potensi itu beliau beserta Komunitas Bandung Creative City Forum (BCCF) melaksanakan program Kampung Kreatif yang mengedepankan ekonomi kreatif berbasis kesenian sunda (seni pentas dan seni kriya sunda) dan mendapat antusias yang baik dari masyarakat sekitar. Saat kini pasar ekonomi kreatif telah memasuki pasar internasional (Belanda dan Amerika). Tahun 2016 Kampung kreatif ini terus melakukan perbaikan dan penambahan fasilitas kampung untuk menjadi Kampung wisata yang mewadahi kegiatan wisata kampung. Dalam pembentukan kampung kreatif terdapat berbagai pengubahan yang dilakukan dari tataan ruang sebelumnya hingga pengubahan tataan ruang untuk mendukung kegiatan kreatif. Sehingga diperlukan adaptasi terhadap ruang-ruang baru yang tercipta. Penelitian ini akan membahas bagaimana pengubahan tatanan ruang yang terjadi dan dampak pengubahan tersebut terhadap tatanan spasial kampung Dago Pojok.

Pengubahan tataan ruang fisik dan kegiatan untuk mewadahi kegiatan wisata kampung terjadi pada berbagai lokasi dengan intensitas tinggi serta faktor pengubahan pelaku penguna, menimbulkan pengubahan yang signifikan pada tataan.

\section{ANALISA}

\subsection{KAMPUNG (KOTA) KREATIF}

Kampung kota merupakan permukiman heterogen di dalam atau di sekelilling suatu

kota, dimana terjadipengubahan secara bertahap dari karakteristik pedesaan ke arah karakteristik perkotaan dan terdapat kepadatan yang tinggi serta sedikitnya fasilitas pelayanan untuk masalahmaslah lingkungan dan perumahan (Concarplan-Sangkriang JUDC, 1983:3).

\section{Kampung Kreatif sebagai Program PIPPK}

Kampung Juara merupakan salah satu kebijakan dalam Kebijakan Program inovasi Pembangunan dan pemberdayaan kewilayahan (PIPPK) kota Bandung 2013-2018. Tidakan lanjut dari Kampung Juara maka terdapat diterbitkan Intruksi Walikota Bandung No. 02 Tahun 2013 tentang Rencana Aksi Menuju Bandung Juara pada alinea ke 4 no 1 E. Kampung Kreatif merupakan perwujudan dari Program Kerja Kampung Juara yang merupakan batang tubuh untuk mewujudkan Bandung Juara. Program pemerintah mengenai Kampung Kreatif adalah menggali potensi masyarakat kampung kota secara humanis dengan arahan dan 
pelatihan yang dilakukan akademisi, sehingga menghasilkan produk unggulan pada kampung tersebut.

\section{Karakteristik Morfologis Kampung Kota}

Karakteristik morfologis kampung kota terbentuk secara alamiah dan tidak terencana dimana tidak menganut proses pembangunan lingkungan pemukiman. Menurut Hebert: 1973 dalam Hadi Yunus, ruang lingkup kajian morfologi mencakup pola bentuk fisikal dari lingkungan kekotaan yang dapat diamati dari berberapa unsurnya, meliputi:

1. Sistem jalan yang ada: Pembentukan tatanan jalan dan pemukiman kampung kota membentuk tatanan linear. Pembentukan dan penempatan ruang tidak berdasarkan pada penetapan fungsi ruang terlebih dahulu

2. Blok-blok bangunan baik daerah hunian ataupun non-hunian pada kampung kota dilakukan secara self organized bedasarkan kepentingan dan kesepakatan. Kepadatan bangunan tinggi mencapai $80-90 \%$ coverage area.

3. Bangunan individual pada kampung kota tidak terencana dan tumbuh secara terus menerus, sehingga menghasilkan pola pemukiman irregular pattern dan memiliki orientasi utama bangunan menghadap kepada jalan utama

Dalam kasus kampung-kota fungsi-fungsi ruang ditempatkan menyesuaikan dengan kondisi ruang yang ada. Secara singkat pengaturan dan penataan ruang di dalam rumahrumah di kampung-kota, sebagian besar mengikuti prinsip "fungsi mengikuti bentuk" bukan "bentuk mengikuti fungsi". 1

\section{Behavior Setting sebagai Pendekatan}

Behavior setting merupakan kajian mengenai wujud dari ruang aktivitas serta hubungan antara sistem aktivitas dengan seting fisik tertentu. Roger Barker mengkombinasikan behavior setting dengan sistem tataan ruang dan aktivitasnya, yang terdiri dari Standing Pattern of Behavior, Milieu, Synomorphy dan Time Period. Fit merupakan kesesuaian antara bentuk dan kapasitas suatu tempat, elemen penghubung, dan peralatannya dengan pola dan kuantitas aktivitas pemakainya. Kesesuaian antara latar lingkungan dengan perilaku, termasuk tingkat adaptasi mereka dengan apa yang akan dilakukan di masa depan. ${ }^{2}$ Konsepsi Fit Theory dan Affordabilitas tatanan ruang fisik dan relasinya dengan tatanan ruang aktivitas dapat dikaji melalui elemen-elemen arsitektural pembentuk tatanan ruang tersebut. Dalam Haryadi, Setiawan, B. 1995. Arsitektur Lingkungan dan Perilaku, terdapat 5 elemen arsitektural yang mempengaruhi perilaku manusia sebagai pembentuk tataan ruang adalah ruang, bentuk \& dimensi, warna, perabot \& penataan dan penerangan.

Dalam kajian perubahan tataan ruang pada kampung kota menjadi kampung kreatif terdapat behavior setting yang berbeda antara ruang pemukiman dan ruang wisata kampung yang bersifat temporer. Perubahan tataan ruang fisik disebabkan adanya Standing Pattern of Behavior, Milieu, Synomorphy dan Time Period yang berbeda, untuk mencapai nilai fitness dan affordability antara ruang dan kegiatan.

Perubahan tataan ruang akibat perubahan (intensitas, kapasitas, pelaku, periode waktu dan kegiatan) pada beberapa area kampung, menyebabkan adanya perubahan tatanan spasial Kampung Dago Pojok. Sehingga adanya kegiatan wisata kampung kreatif mengakibatkan perubahan pola kegiatan dan tataan ruang. Hal ini disebabkan oleh keterbatasan ruang yang menjadi ciri khas kampung kota sehingga manusia melakukan beragam bentuk adaptasi untuk bisa mewadahi kebutuhan akan ruang kegiatan.

\footnotetext{
${ }^{1}$ Widjaja, Pele. (2013). Kampung-Kota Bandung. Yogyakarta: Graha Ilmu. hal 10

${ }^{2}$ Lynch, Kevin, 1981, Good City Form, The MIT Press, Massachusetts, EEUU. hal 151
} 


\subsection{KAMPUNG KREATIF DAGO POJOK}

Kampung Dago Pojok merupakan sebuah urban pocket akibat pembangunan tidak terencana pada Kawasan Dago dengan intensitas kepadatan penduduk yang tinggi. Kampung Kreatif terbentuk pada tahun 2010 yang diprakasai oleh Bapak Rahmat Jabaril dan Bandung Creative City Forum. Dalam masa perubahan kampung kota menjadi kampung kreatif terjadi pengembangan kualitas tataan ruang fisik dengan bertambahnya dekorasi mural maupun lukisan, pengubahan fungsi ruang dan penambahan fasilitas pada Kampung Dago Pojok.

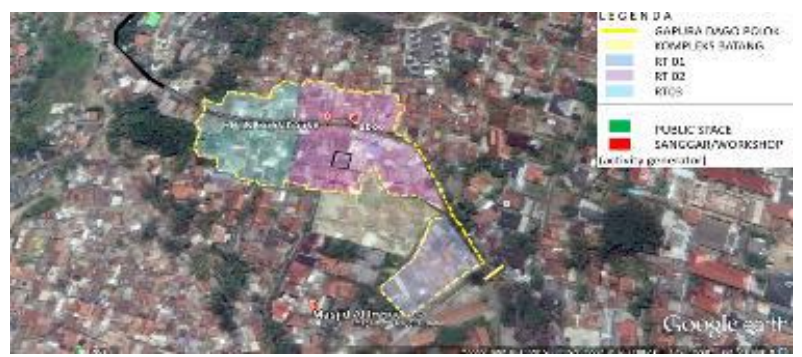

Figur 1. Batas Administrasi Lokasi Amatan

(Sumber: Google Earth, 2016)

\section{Tatanan Fisik-Spasial Kampung Dago Pojok}

Kampung Dago Pojok berada pada Bandung bagian Utara, Kelurahan Dago RW 03. Dago Pojok termasuk dalam Wilayah Bandung Barat dengan SWK Cibeunying. Batas-batas wilayah Kampung Dago Pojok adalah sebagai berikut:

Utara : daerah Kabupaten Bandung

Selatan : Kelurahan Lebak Siliwangi

Barat : Sungai Cikapundung dan Kelurahan Ciumbuleuit, Kec Cidadap

Timur : Kelurahan Cigadung, Kelurahan Sekeloa, Kel Lebak Gede.

Tata guna lahan pada Kampung Dago Pojok, sebagian besar digunakan sebagai pemukiman padat penduduk. Fungsi hunian mix use dan area komersil berada pada tepi badan jalan Dago Pojok. Terdapat sarana pendidikan, dari SD hingga SMA, terdapat rumah baca Taboo untuk meningkatkan edukasi warga.

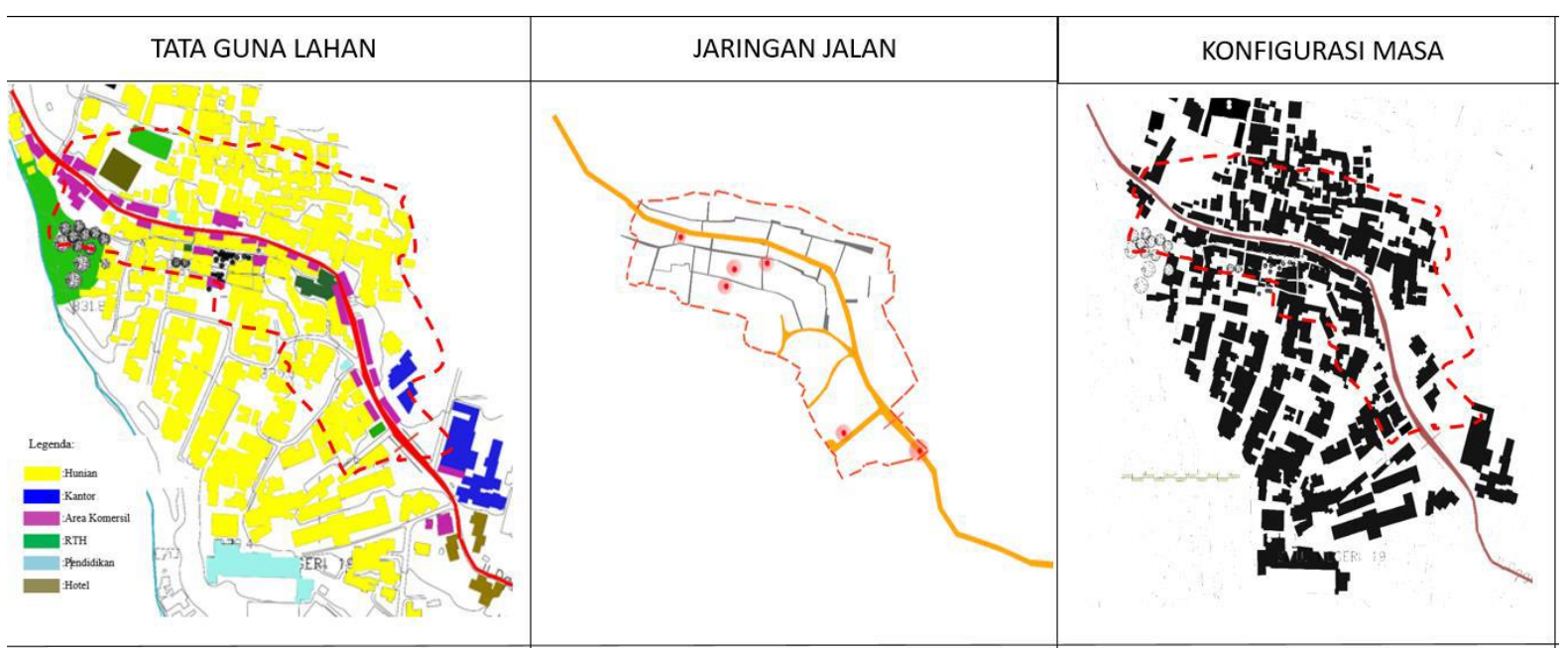

Figur 2. Morfologi Kampung Dago Pojok 
Jaringan Jalan pada kawasan Dago Pojok memiliki pola jaringan jalan spinal. Jaringan jalan primer memiliki lebar badan jalan bervariasi, lebar 7 meter hingga 6 meter. Sedangkan jalan sekunder pada kawasan Dago Pojok memiliki lebar 5 meter hingga 1 meter. Ruang terbuka hijau terdapat di beberapa kavling penghuni yang belum diolah dan dihibahkan sementara kepada masyarakat.

Konfigurasi masa kampung kota, berorientasi pada jalan utama, yaitu Jalan Dago Pojok, dengan konfigurasi masa irregular pattern. Orientasi bangunan menuju ke jalan utama, hal ini menunjukkan pemukiman terbentuk akibat adanya infrastruktur jalan terlebih dahulu yang kemudian diikuti oleh pembangunan pemukiman. Sehingga bangunan memiliki satu orientasi, yaitu berorientasi pada jalan utama. Infrastruktur teknis meliputi jaringan air PDAM, jaringan listrik bersumber dari PLN dan PLTA, serta tersedia MCK di beberapa area yang berdekatan dengan sumber mata air.

\section{Karakteristik Penduduk Kampung Dago Pojok}

Guyub merupakan salah satu karakter sosial penduduk kampung Dago Pojok. Keguyuban terjadi karena hubungan kekeluargaan secara legal maupun emosional. Penghuni dari Kampung Dago Pojok merupakan satu sanak family antar rumah tangga satu dengan rumah tangga lainnya. Setiap generasi memiliki keturunan dan memiliki rumah yang berdekatan, terjadi pengulangan pada generasi selanjutnya dan terbentuk suatu pemukiman kampung kota.

Tabel 1. Tingkat Pendidikan Warga

\begin{tabular}{|l|c|c|c|}
\hline \multicolumn{1}{|c|}{ Pendidikan } & RT01 & RT 02 & RT03 \\
\hline Belum Sekolah & 17 & 58 & 86 \\
\hline Usia 7-45 tahun tidak pernah selcolah & - & - & 19 \\
\hline Pernah Sekolah SD tapi tidak tamat & 4 & 4 & 36 \\
\hline Masih SD atau sederajat & 0 & 61 & 217 \\
\hline Tamat SD atau sederajat & 69 & 86 & - \\
\hline SLTP/sederajat & 49 & 65 & 109 \\
\hline SLTA/sederajat & 121 & 145 & 178 \\
\hline D-1 & - & 10 & 25 \\
\hline D-2 & 1 & 5 & 36 \\
\hline D-3 & 30 & 24 & 47 \\
\hline S-1 & 33 & 111 & 61 \\
\hline S-2 & 7 & 30 & 35 \\
\hline S-3 & 5 & 4 & 25 \\
\hline Total & $\mathbf{3 3 6}$ & $\mathbf{6 0 3}$ & $\mathbf{7 2 9}$ \\
\hline
\end{tabular}

Tabel 2. Mata Pencaharian Warga

\begin{tabular}{l|c|c|c|}
\hline \multicolumn{1}{|c|}{ Mata Pencaharian } & RT01 & RT02 & RT03 \\
\hline Buruh Swasta & 95 & 37 & $\mathbf{1 4 2}$ \\
\hline Pegawai Negri Sipil & 24 & - & 35 \\
\hline Pengrajin & - & 10 & 2 \\
\hline Pedagang & 6 & 3 & 16 \\
\hline Penjahit & - & 5 & 1 \\
\hline Tukang Batu & - & 3 & 17 \\
\hline Tukang Kayu & 14 & 2 & 6 \\
\hline Peternak & - & - & - \\
\hline Montir & - & 3 & 4 \\
\hline Dokter & 2 & 5 & 2 \\
\hline Supir & 7 & - & 15 \\
\hline Pengemudi Becak & - & - & - \\
\hline TNI & - & - & 3 \\
\hline POLRI & 1 & 24 & 5 \\
\hline Pengusaha & 3 & 41 & - \\
\hline Total & $\mathbf{1 6 3}$ & $\mathbf{2 1 1}$ & $\mathbf{2 7 5}$ \\
\hline
\end{tabular}

Data demografi mencatat kepadatan penduduk terkonsentrasi pada teritori RT 03, sebanyak 836 jiwa, pada RT 02 tercatat 629 jiwa berada pada RT02 dan 395 jiwa pada RT 01. Data demografi kependudukan mencatat bahwa, mayoritas penduduk pada Kampung Kreatif Dago Pojok memiliki latar belakang pendidikan cukup baik, tercatat bahwa mayoritas penduduk memiliki latarbelakang pendidikan SMA dengan mata pencaharian terbesar adalah buruh swasta dan pengusaha. 
Kakteristik kegiatan sehari-hari warga seperti kegiatan domestik pada umumnya, terdapat kegiatan pendidikan, kegiatan jual-beli pada area komersil di sepanjang Jalan Dago Pojok, kegiatan MCK dan kerja bakti untuk membersihkan dan membangun atau memperbaiki fasilitas wisata setiap minggunya. Kegiatan wisata kampung kreatif meliputi berbagai hal mengenai wisata budaya untuk memperkenalkan kebudayaan masyarakat Sunda ke publik.Berikut merupakan detail mengenai kegiatan dan wisata kampung bagi para wisatawan ;

Tabel 3. Tabel Kegiatan Wisata dan Lokasi Wisata

\begin{tabular}{|l|l|l|}
\hline No. & Kegiatan Wisata Kampung & Lokasi \\
\hline 1. & Pawai & Gerbang Kampung RT 01 \\
\hline 2. & Menonton Pagelaran Gondang & Halaman terbuka RT 03 \\
\hline 3. & Menonton Pagelaran Wayang Golek & Amphitheatre RT 02 \\
\hline 4. & Menonton Pagelaran Jaipong & Amphitheatre RT 02 \\
\hline 5. & Belanja Souvenir & Koridor sekunder Gg Mama Adi \\
\hline 6. & Workshop kreatif/Eksperimen kreatif & $\begin{array}{l}\text {-Koridor sekunder Gg Mama Adi } \\
- \text { Amphitheatre RT 02 }\end{array}$ \\
\hline 7. & Melihat proses produksi Wayang Golek & Rumah Bpk Nanang RT 02 \\
\hline 8. & Melihat proses produksi Kriya & Rumah Bpk Charli RT 02 \\
\hline 9. & Melihat proses produksi alat Musik Bambu & Rumah Bpk Akim RT 07 \\
\hline 10. & Tur Wisata Kampung & $\begin{array}{l}\text { Starting point: RT 01- } \\
\text { Ending point RT 07 }\end{array}$ \\
\hline
\end{tabular}

\section{Lokasi Wisata Kampung Kreatif}

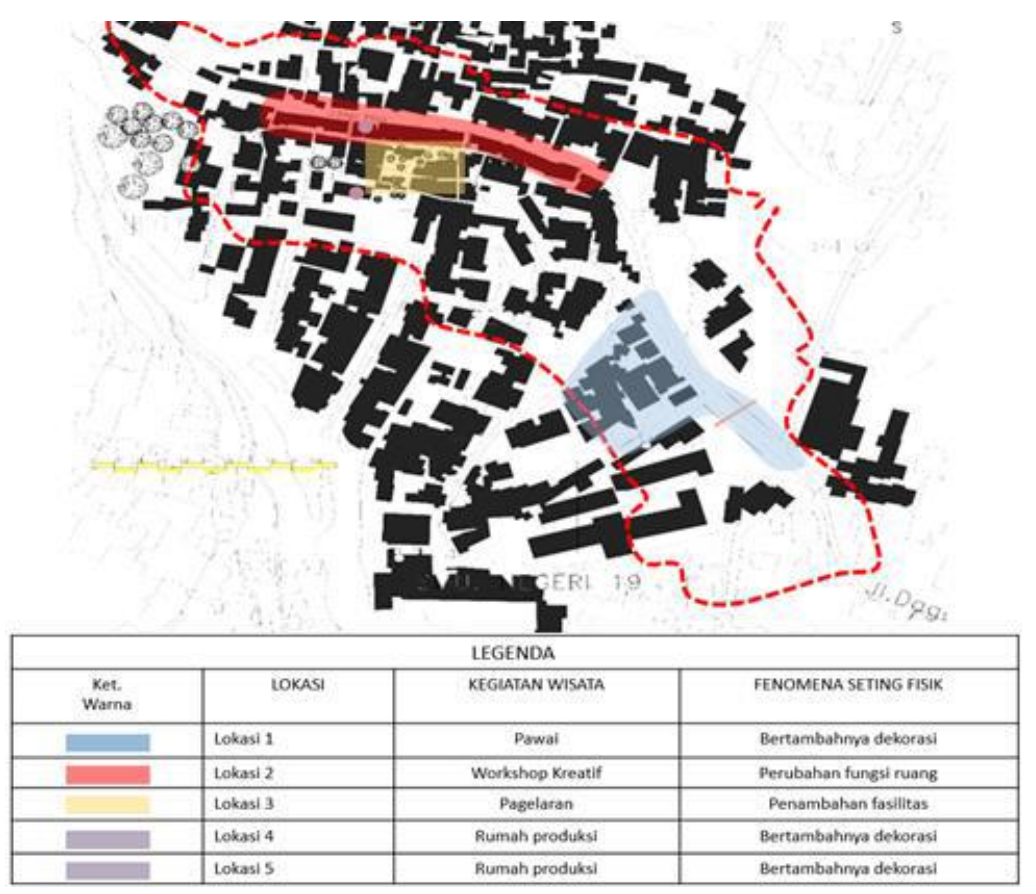

Figur 3. Ruang Lingkup Lokasi Penelitian

Lokasi amatan penelitian berada pada 5 titik yang berperan aktif dalam menjalankan program wisata kampung kreatif. Lokasi 1 berada pada gerbang utama RW 03 RT 01 yang digunakan sebagai sirkulasi pawai. Lokasi 2 berada pada koridor sekunder Gang Mama Adi 1 - 2, digunakan sebagai workshop. Lokasi 3 berada pada Amfiteater RT 02, Lokasi 4 dan 5 merupakan workshop produksi dari usaha kreatif warga. 


\section{Pengubahan Tataan Ruang Fisik Akibat Kegiatan Wisata Kampung Kreatif Dago Pojok}

Fit merupakan kesesuaian antara bentuk dan kapasitas suatu tempat, elemen penghubung, dan peralatannya dengan pola dan kuantitas aktivitas pemakainya., terdapat dua pengubahan yang terjadi akibat adanya stimulus dari kegiatan wisata kreatif Kampung Dago Pojok, pengubahan merupakan upaya untuk membentuk suatu tatanan ruang yang fit dalam menjalankan kegiatan wisata kampung kreatif.

Tabel 4. Pengubahan yang terjadi pada Tataan Ruang

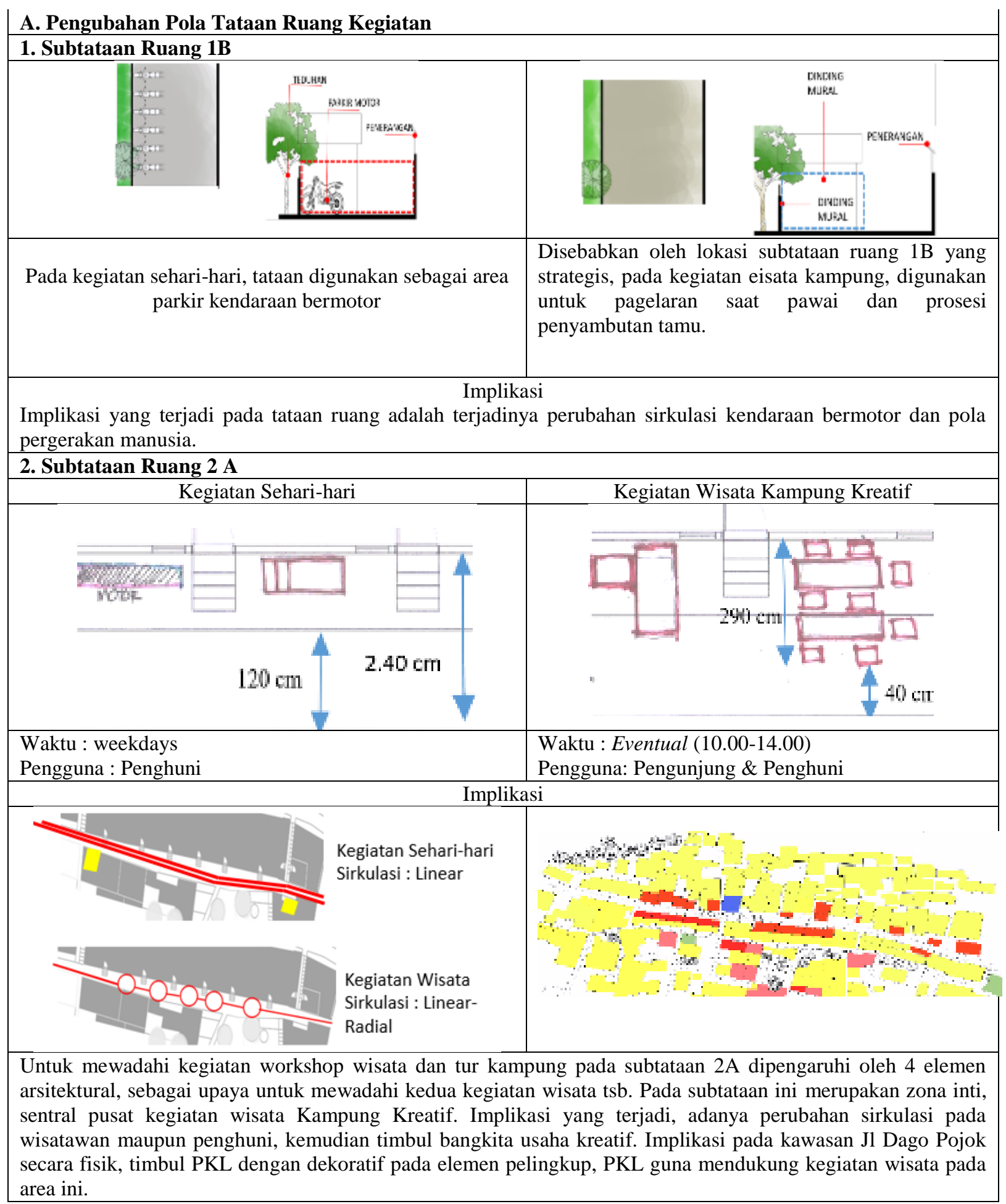




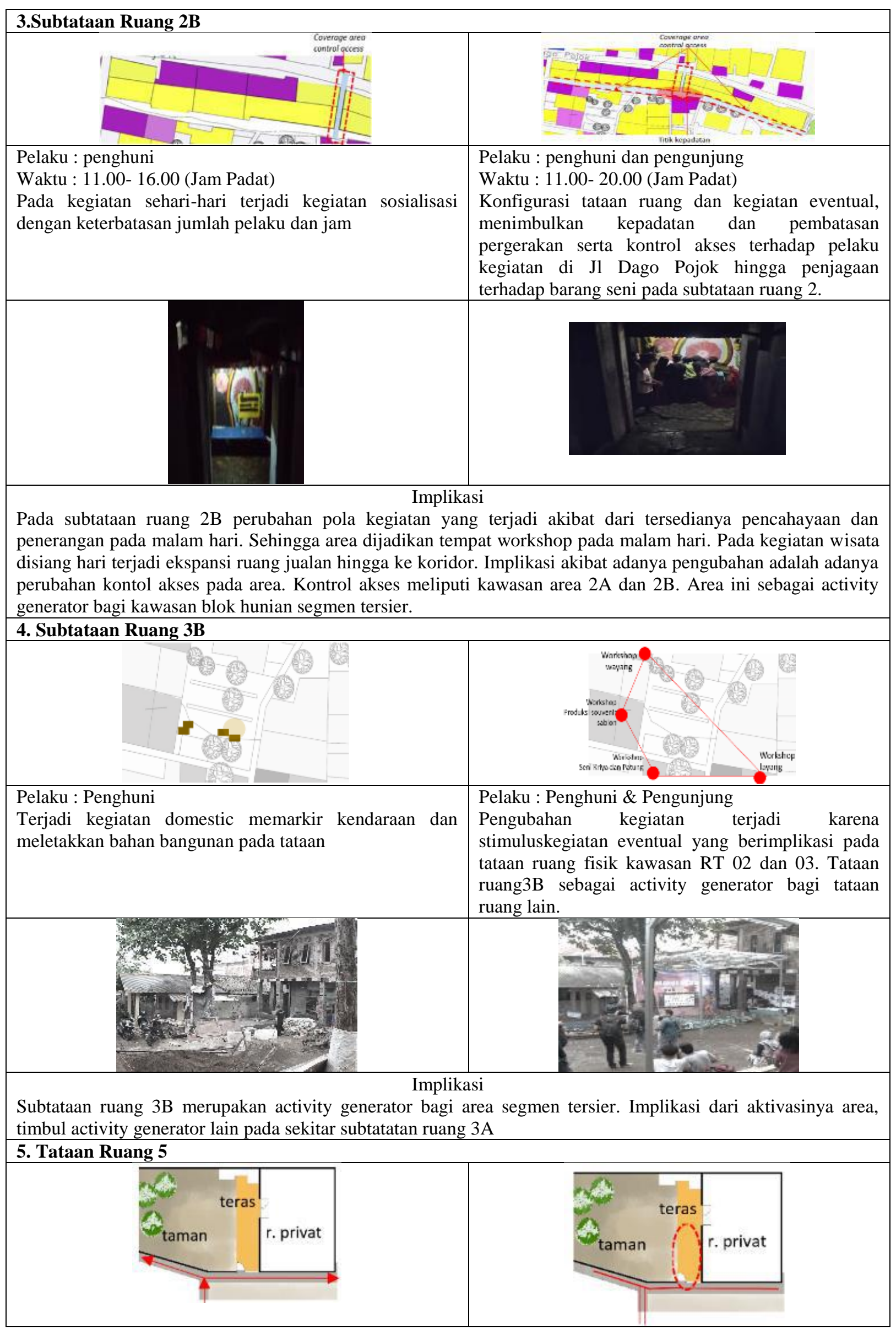




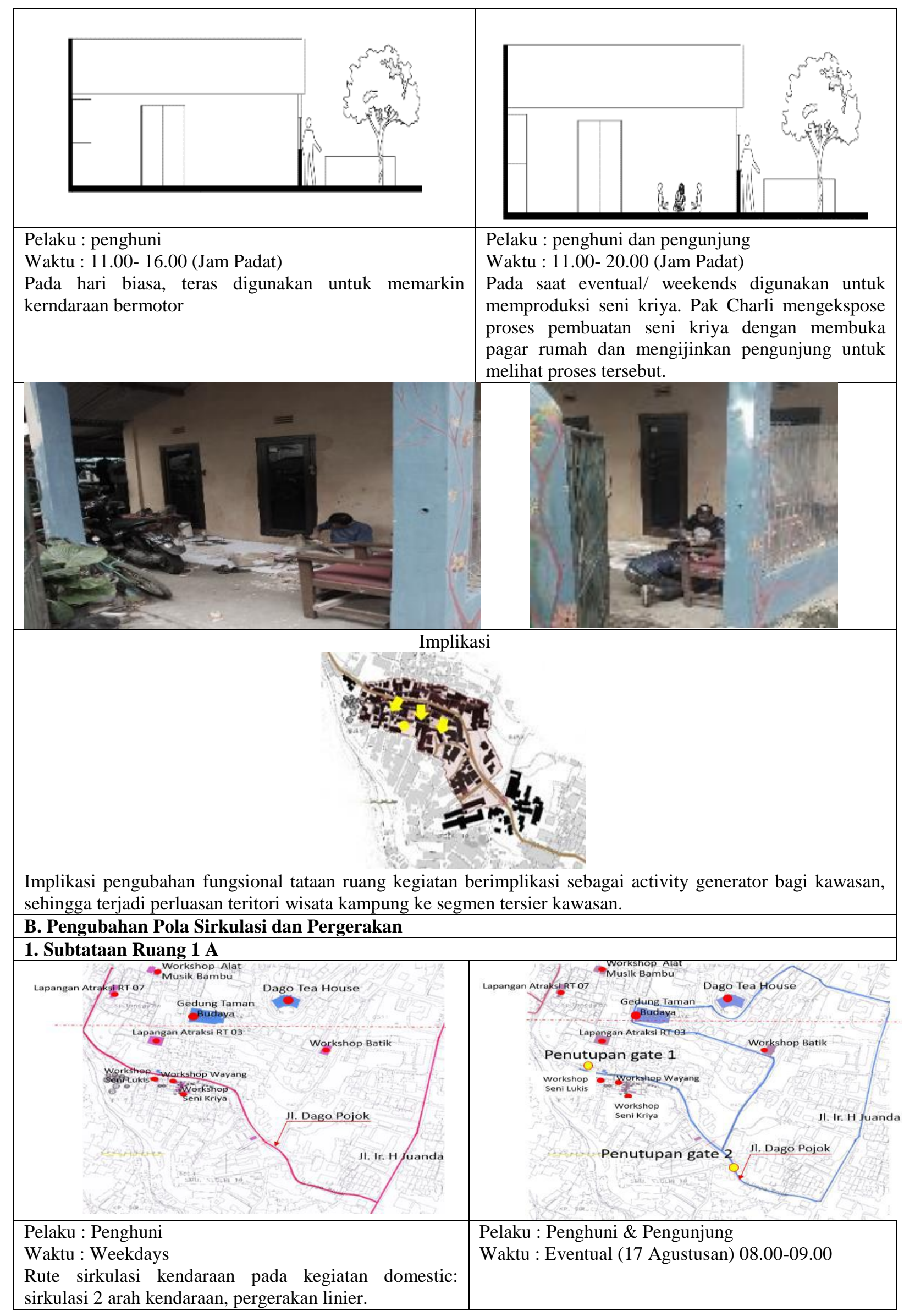




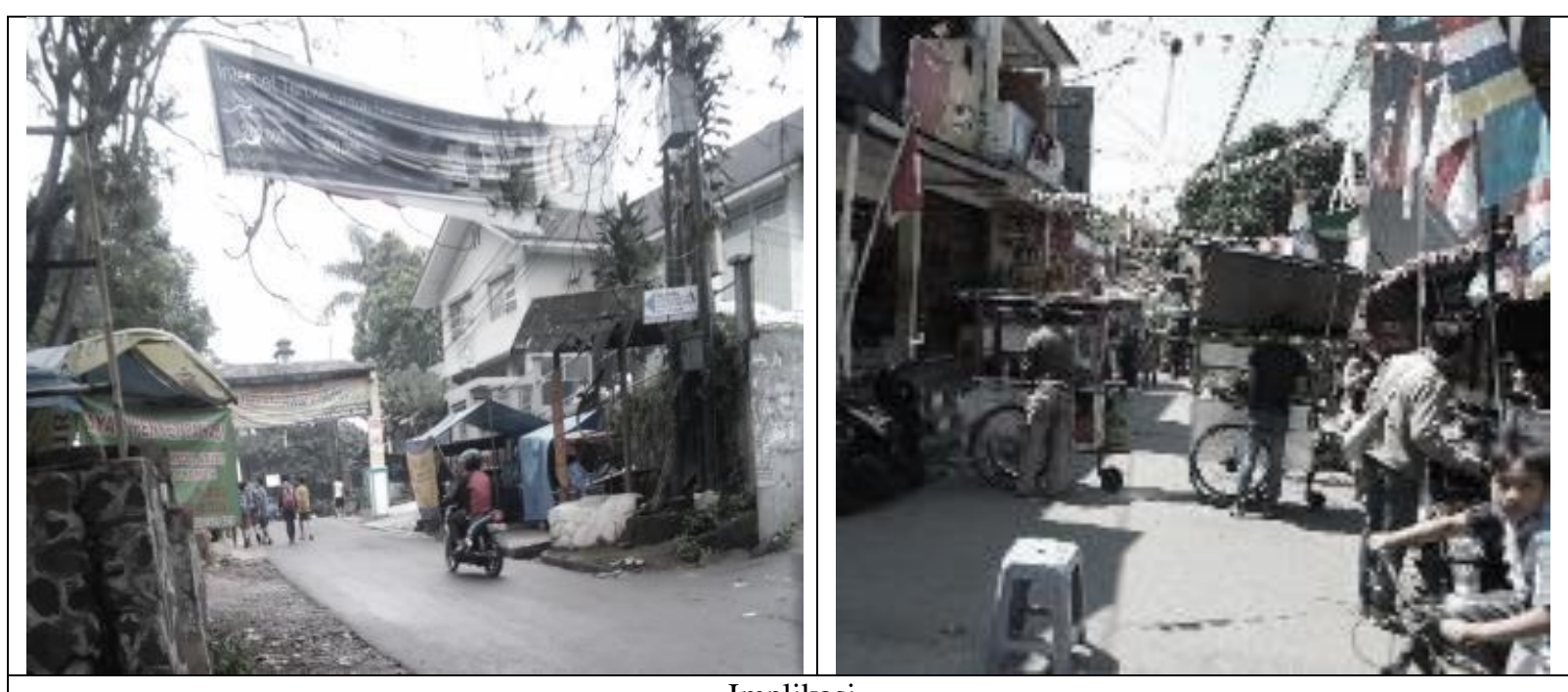

Implikasi

Pada tataan ruang terjadi bentuk dimensi dan perabot penataan. Perubahan dimensi pada subtataan, pada awalnya tersedia ruang pada badan jalan $7 \mathrm{~m}$, saat terjadi pawai terdapat penutupan oleh PKL, pengurangan dimensi : $0.80 \mathrm{~cm}$. Penataan PKL pada badan jalan sebagai elemen semifixed untuk mewadahi ruang kegiatan. Implikasi yang terjadi pada tataan ruang adalah terjadinya perubahan sirkulasi kendaraan bermotor dan pola pergerakan manusia.

Kapasitas pengguna sirkulasi rendah
andatan Ruang 3 A




\subsection{PENGARUH KEGIATAN WISATA KAMPUNG KREATIF TERHADAP PENGUBAHAN TATA RUANG KEGIATAN DAN TATANAN SPASIAL KAMPUNG}

Ruang sebagai ruang arsitektural memiliki elemen-elemen arsitektural yang mempengaruhi aktivitas penghuni tersebut. Elemen arsitektural yang mempengaruhi perilaku manusia diantaranya: ruang, bentuk dan dimensi, perabot dan penataan, warna serta penerangan dan pencahayaan. Berikut merupakan table rekapitulasi dari pengaruh elemenelemen arsitektural tersebut.

Tabel 5. Implikasi Pengubahan Tataan Ruang

\begin{tabular}{|c|c|c|c|c|c|c|}
\hline \multirow[b]{2}{*}{$\begin{array}{l}\text { Subtataan } \\
\text { Ruang }\end{array}$} & \multirow[b]{2}{*}{$\begin{array}{c}\text { Implikasi } \\
\text { pengubahan }\end{array}$} & \multicolumn{5}{|c|}{ Elemen Arsitektural } \\
\hline & & Ruang & $\begin{array}{c}\text { Bentuk } \\
\text { \&. Dimensi }\end{array}$ & $\begin{array}{l}\text { Perabot } \\
\& \\
\text { Penataan }\end{array}$ & Warna & $\begin{array}{c}\text { Pencahayaz } \\
\text { n \& } \\
\text { Penerangan }\end{array}$ \\
\hline $1 \mathrm{~A}$ & $\begin{array}{l}\text { Pengubahan Pola } \\
\text { Sirkulasi dan Pola } \\
\text { Pergerakan }\end{array}$ & & $\sqrt{ }$ & $\sqrt{ }$ & & \\
\hline 1B & $\begin{array}{l}\text { Pengubahan Pola } \\
\text { Kegiatan }\end{array}$ & & $\sqrt{ }$ & & & \\
\hline $2 \mathrm{~A}$ & $\begin{array}{l}\text { Pengubahan Pola } \\
\text { Kegiatan }\end{array}$ & & $\sqrt{ }$ & $\sqrt{ }$ & $\sqrt{ }$ & $\sqrt{ }$ \\
\hline $2 A$ & $\begin{array}{l}\text { Pengubahan Pola } \\
\text { Sirkulasi dan Pola } \\
\text { Pergerakan }\end{array}$ & & $\sqrt{ }$ & $\sqrt{ }$ & & \\
\hline $2 \mathrm{~B}$ & $\begin{array}{l}\text { Pengubahan Pola } \\
\text { Kegiatan }\end{array}$ & & & & $\sqrt{ }$ & $\sqrt{ }$ \\
\hline $3 \mathrm{~A}$ & $\begin{array}{l}\text { Pengubahan Pola } \\
\text { Sirkulasi dan Pola } \\
\text { Pergerakan }\end{array}$ & $\sqrt{ }$ & & $\sqrt{ }$ & & \\
\hline $3 \mathrm{~B}$ & $\begin{array}{l}\text { Pengubahan Pola } \\
\text { Kegiatan }\end{array}$ & $\sqrt{ }$ & & $\sqrt{ }$ & & \\
\hline 4 & $\begin{array}{l}\text { Pengubahan Pola } \\
\text { Sirkulasi dan Pola } \\
\text { Pergerakan }\end{array}$ & & $\sqrt{ }$ & $\sqrt{ }$ & & \\
\hline 5 & $\begin{array}{l}\text { Pengubahan Pola } \\
\text { Kegiatan }\end{array}$ & & $\sqrt{ }$ & & & \\
\hline
\end{tabular}

Elemen-elemen arsitektural sebagai pengubah tataan selanjutnya akan dipetakan secara kawasan adalah sebagai berikut:

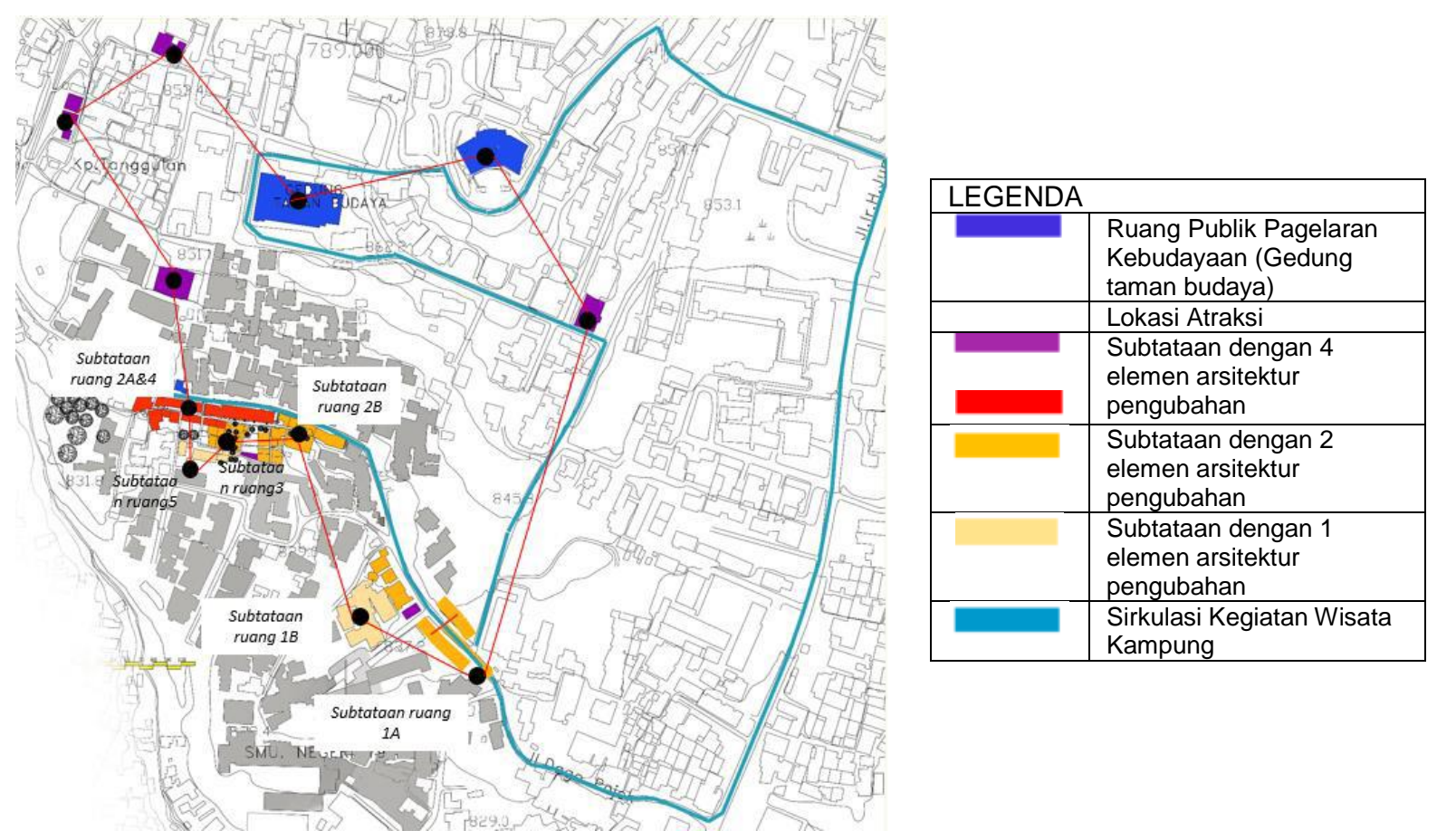

Figur 4. Pemetaan Temuan pada Kawasan Dago Pojok 
Pada pemetaan temuan, ditemukan bahwa pengaruh elemen arsitektur terhadap subtataan ruang terbesar terlihat pada sentral kawasan Dago Pojok. Keterkaitan area amatan satu dengan area amatan lainnya membentuk suatu pola radial pada kawasan Dago Pojok. Dari pemetaan tersebut akan dikaji perubahan tatanan spasial pada Kampung Dago Pojok.

Tabel 6. Perubahan Tatanan Spasial Kampung Dago Pojok

\section{Perubahan Zonasi}

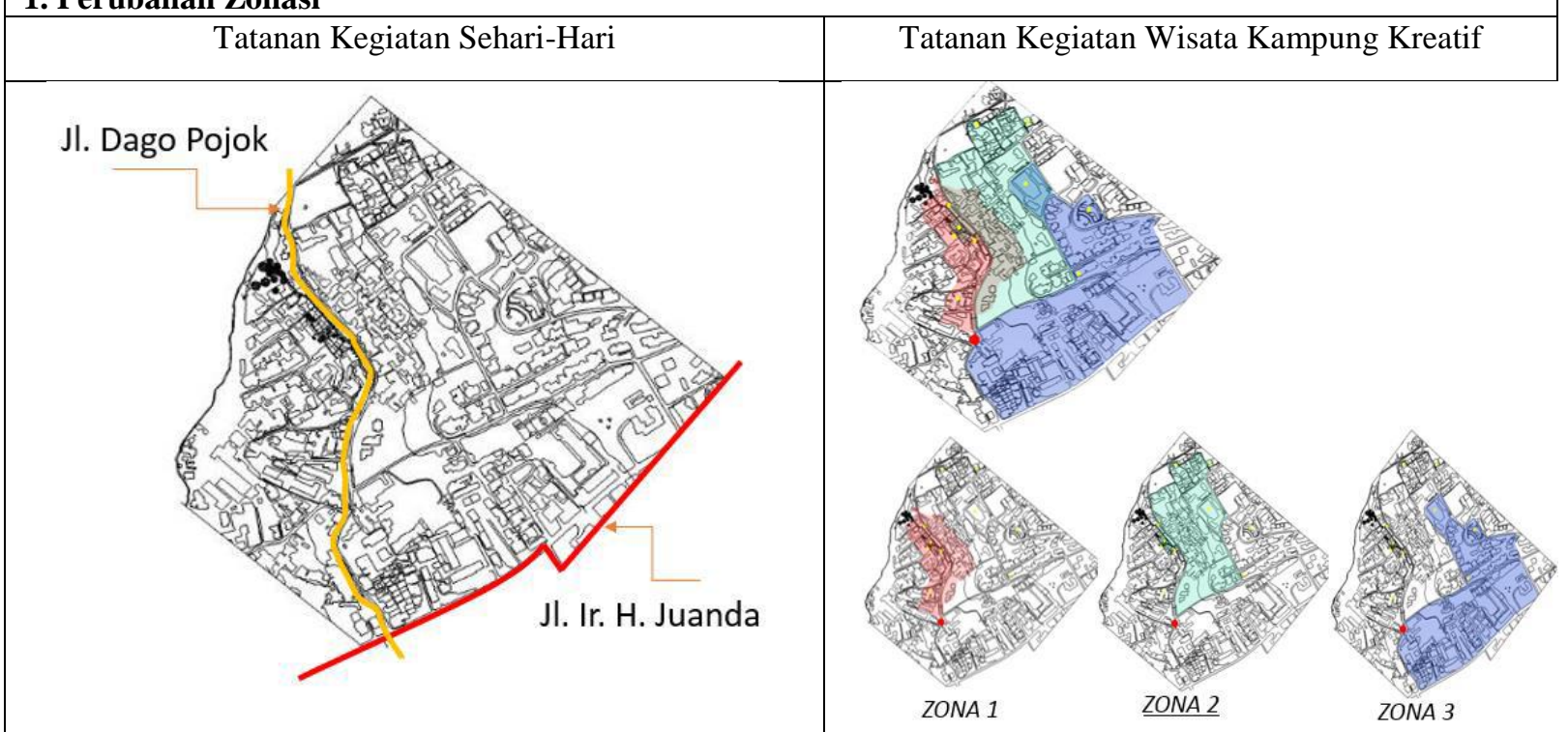

Pengubahan struktur tata ruang secara zonasi terdapat 3 zona pada kegiatan wisata kampung kreatif. Zona 1 meliputi zona utama, sentral kegiatan wisata kampung. Zona 2 : zona kegiatan tur kampung. Zona 3 : sirkulasi pawai kebudayaan.

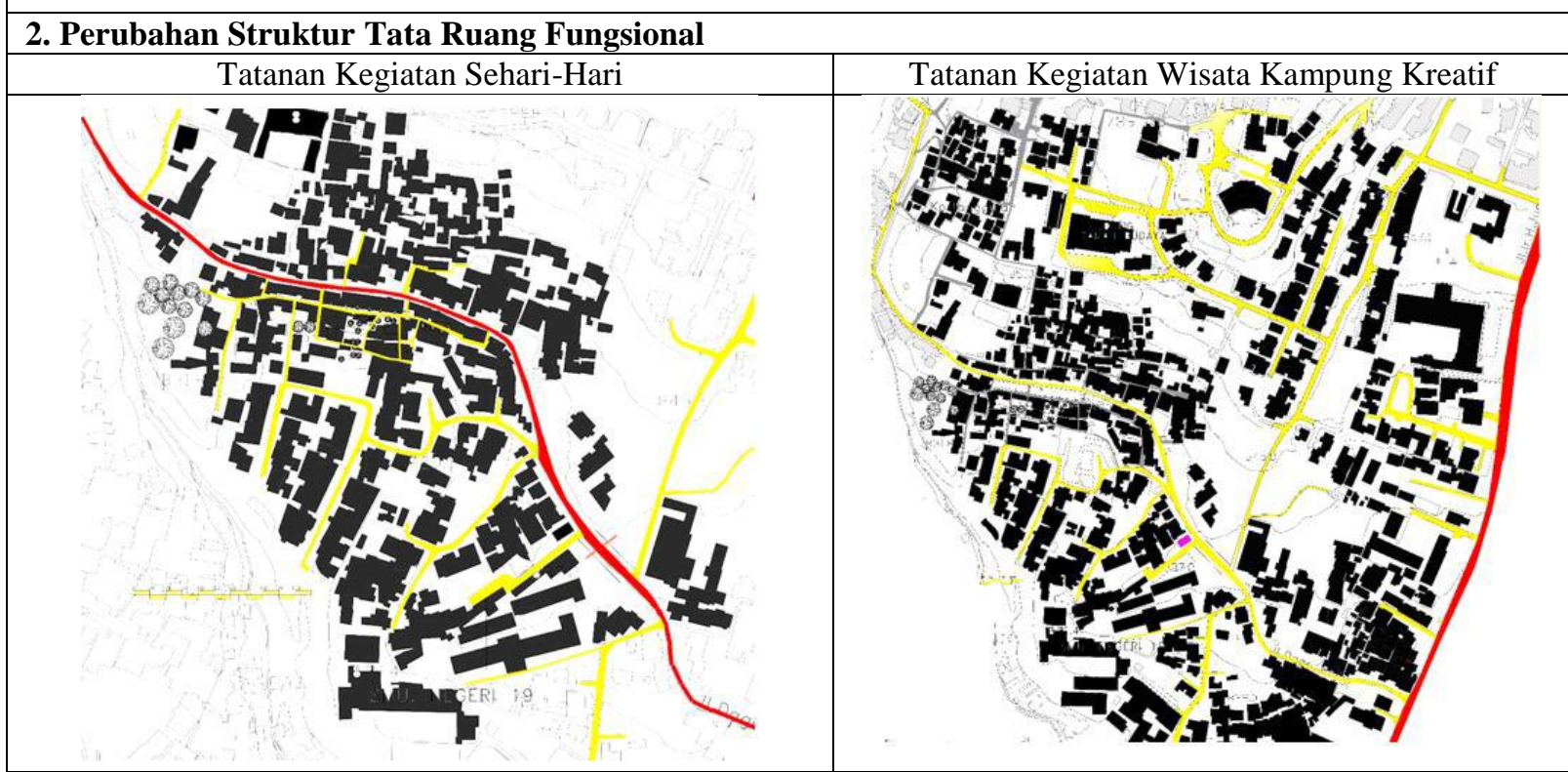

Perubahan jaringan sarana prasarana, memiliki 1 konsentrasi kegiatan sebagai area sentral wisatawan : zona inti. Perubahan terjadi, konsentrasi kegiatan tidak hanya pada ruas Jalan Dago Pojok, melainkan pada ruas Jalan Bukit Dago dan J1. Ir. H Juanda. Secara fungsional terdapat ekspansi jaringan sarana prasarana. 


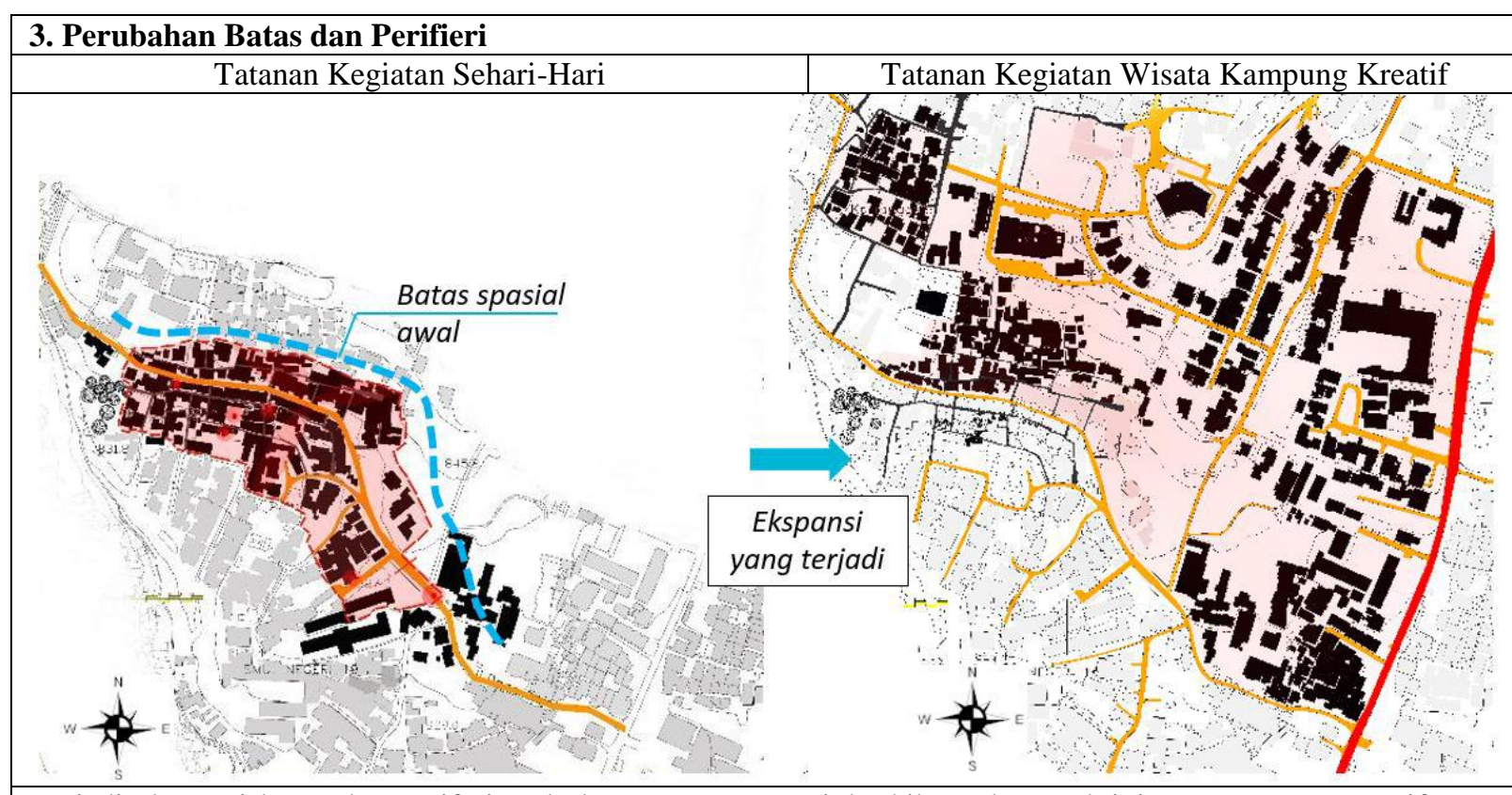

Terjadi ekspansi batas dan periferi pada kawasan Dago Pojok akibat adanya aktivitas Kampung Kreatif yang berimplikasi pada perubahan sirkulasi dan tautan antar area atraksi, terkait dengan bertambahnya activity generator pada kawasan sehingga terjadi ekspansi batas ke bagian utara.

\section{Perubahan Sirkulasi Kawasan}

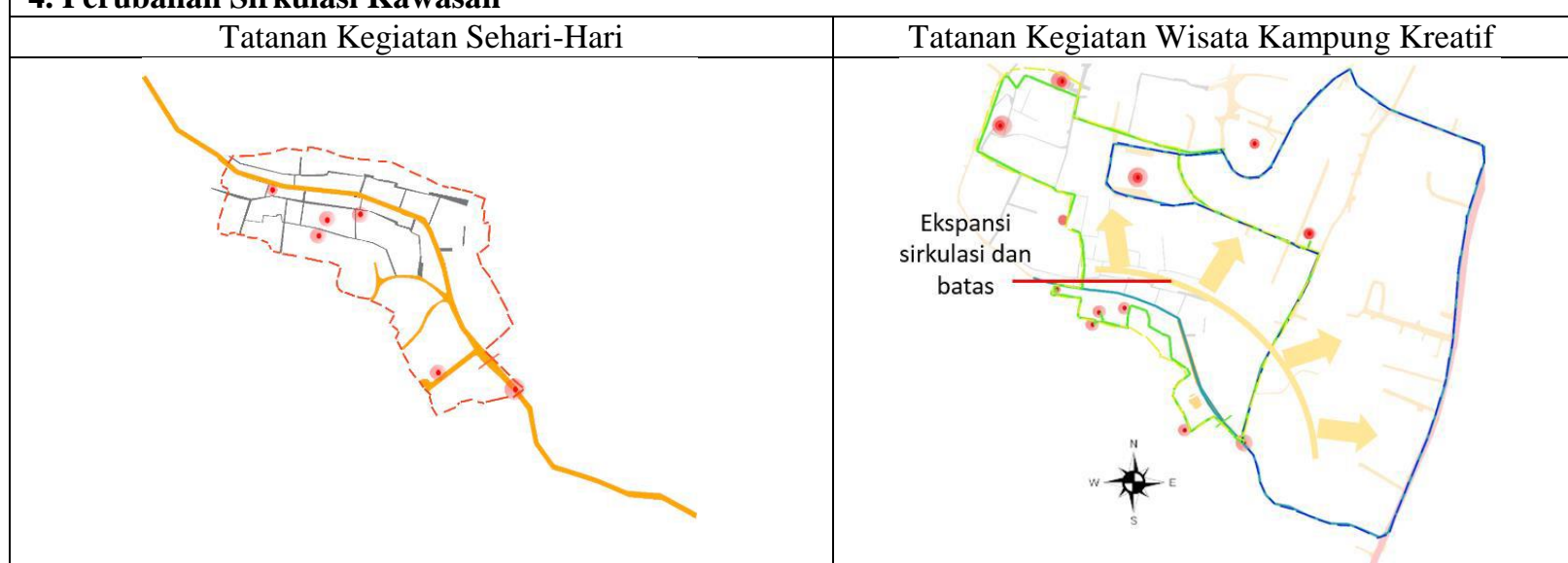

Saat kegiatan wisata kampung kreatif terdapat ekspansi pola jaringan jalan pada kawasan Dago Pojok, ekspansi jaringan jalan, sebagai media tautan antara area atraksi satu dengan area atraksi lainnya. Perubahan pola jaringan jalan dari sistem linear menjadi loop membentuk suatu blok kawasan dengan hirarki dan datum tertentu.

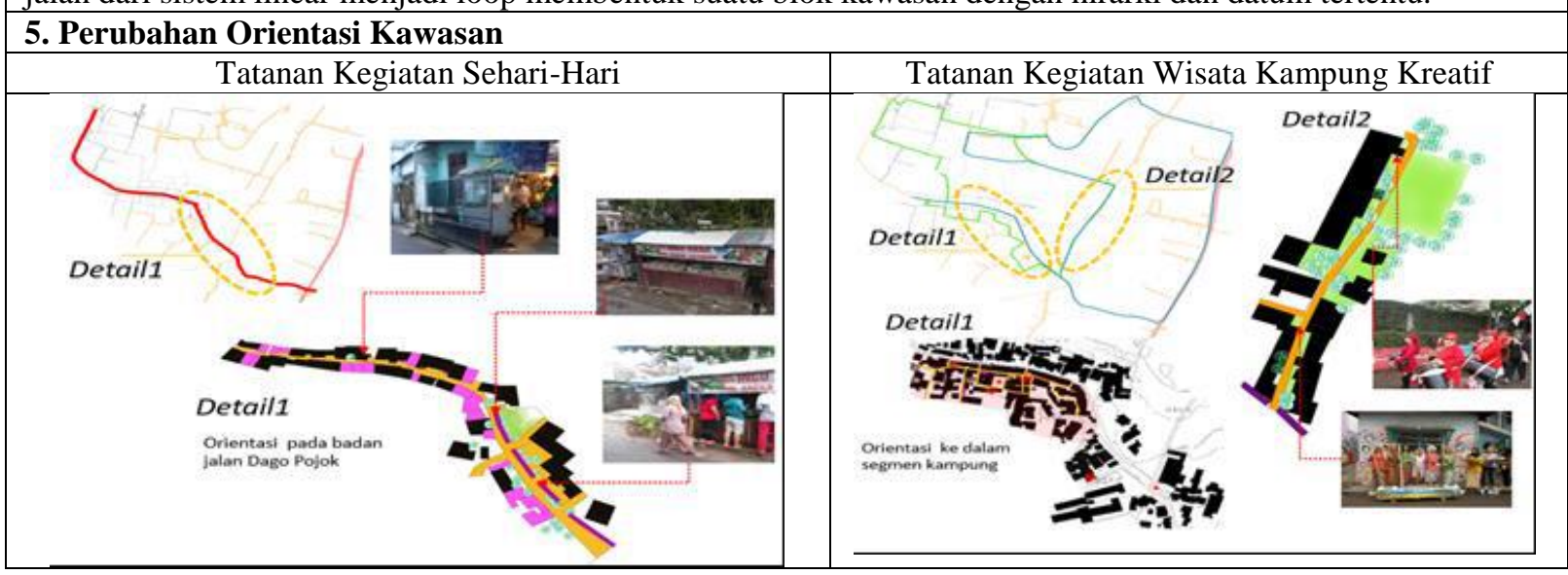




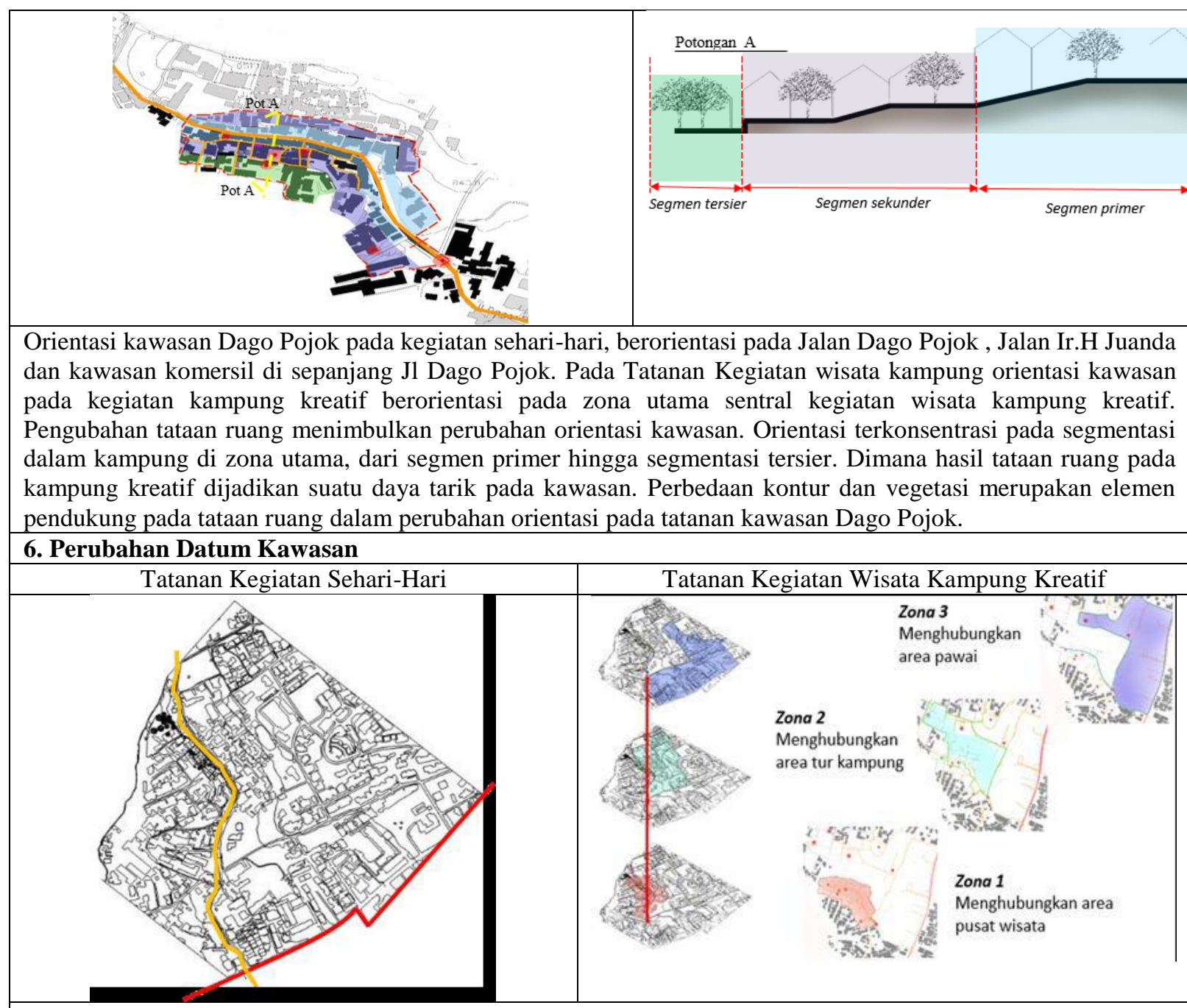

Perubahan datum kawasan sebagai pengikat berubah pada kegiatan wisata kampung kreatif. Pada kegiatan wisata terdapat 3 subdatum yang masing-masing sebagai pengikat blok dan ruang kegiatan.

Subdatum 1: pengikat kegiatan utama wisata kampung

Subdatum 2: pengikat kegiatan tur kampung

Subdatum 3: pengikat kegiatan pawai kebudayaan

Pada area gerbang merupakan kawasan primer sebagai representasi Kampung Kreatif Dago Pojok kepada wisatawan sebagai pengikat utama dari ragam kegiatan yang ada di dalam kawasan.

\section{Perubahan Hirarki Kawasan}

\begin{tabular}{l} 
Tatanan Kegiatan Sehari-Hari \\
\hline $\begin{array}{l}\text { Hirarki terbentuk dari kumpulan ruang-ruang utama kegiatan wisata Kampung, yang menjadi pusat utama } \\
\text { kegiatan wisatawan dan kegiatan. Sehingga terdapat tiga zona, yaitu hirarki pusat sebagai penggerak aktivitas } \\
\text { utama dan zona-zona luar sebagai zona pendukung aktivitas dari zona utama. }\end{array}$
\end{tabular}




\section{PENUTUP}

\subsection{KESIMPULAN}

Dari pengumpulan data dan analisis yang telah dilakukan secara keseluruhan, maka dapat dibuat beberapa kesimpulan mengenai penelitian ini, antara lain :

- Bagaimana pengaruh kegiatan wisata Kampung Kreatif terhadap pengubahan tataan ruang kegiatan sehari-hari di Kampung Dago Pojok?

Pengubahan tataan ruang fisik disebabkan oleh program kegiatan wisata kampung kreatif. Program tersebut menuntut perbedaan intesitas dan kapasitas yang berbeda dari kegiatan bermukim. Pengaruh yang terjadi adanya perubahan sirkulasi dan perubahan tataan ruang. Pada tataan ruang 1 yang difungsikan sebagai ruang pawai, membutuhkan ruas jalan untuk ruang sirkulasi pawai dan pembatasan ruang menggunakan elemen semifixed feature, yaitu PKL. Pada tataan ruang 2 yang difungsikan sebagai workshop, menuntut adanya fleksibilitas ruang. Pengubahan yang terjadi dipengaruhi oleh 4 elemen arsitektural, pengubahan yang signifikan ini disebabkan oleh penggunaan ruang sebagai pusat aktivitas kegiatan wisatawan (zona sentral). Pada tataan ruang 3 difungsikan sebagai ruang pagelaran, memerlukan ruang dengan tipologi square, fleksibilitas ruang dan penggunaan elemen semifixed feature sebagai elemen pendukung untuk mewadahi kegiatan. Pada tataan ruang 4 dan 5 merupakan workshop produksi yang berpengaruh sebagai activity generator kawasan.

Pengubahan tataan ruang untuk mencapai nilai fitness dan affordabilitas terhadap kegiatan wisata kampung kreatif menggunakan elemen semifixed feature, disebabkan karakteristik kampung kota yang memiliki kepadatan tinggi, sehingga ketersediaan ruang minim untuk dilakukan pengubahan secara fisik dalam skala besar.

- Apa pengaruh perubahan tataan ruang kegiatan wisata kampung tersebut pada tatanan spasial kampung Dago Pojok?

Pengaruh pengubahan tataan ruang pada beberapa lokasi kawasan menyebabkan terjadinya perubahan tatanan spasial pada kawasan. Dalam hal jaringan sarana prasarana serta batas dan periferi, terjadi ekspansi ke arah dalam segmen tersier kampung dan ekspansi ke arah utara kawasan Dago Pojok.

Pada kegiatan wisata kampung kreatif terdapat pembentukan 3 zonasi, yaitu zona utama (merupakan zona sentral pengunjung), zona sekunder (zona tur kampung wisata, yang menghubungkan setiap ruang atraksi dan usaha kreatif watga) dan zona tersier (zona pawai yang mentautkan area atraksi satu dengan atraksi lainnya). Perubahan zona menyebabkan terjadinya perubahan orientasi kawasan. Pada mulanya, orientasi utama terdapat pada Jl.Dago Pojok, namun orientasi berubah ke segmen tersier kampung sebagai konsentrasi wisatawan. Perubahan selanjutnya terjadi pada datum sebagai pengikat kegiatan. Pada mulanya jalan utama Dago Pojok berfungsi sebagai datum pengikat kawasan, namun pada kegiatan wisata kampung kreatif, terdapat 3 subdatum dengan datum utama terdapat pada area gerbang. Serta terjadi perubahan hirarki kawasan yang terdapat pada zona utama sebagai sentral kegiatan dari pengunjung.Perubahan tatanan yang terjadi akibat pengubahan tataan ruang kegiatan wisata kampung kreatif. Perubahan tatanan spasial diakibatkan oleh tuntutan kebutuhan ruang pada kegiatan wisata Kampung Kreatif. Tatanan fisik tidak mengalami perubahan yang signifikan disebabkan oleh karakteristik pada pemukiman padat penduduk di kampung kota bersifat irregular pattern dengan intensitas yang tinggi dan kapasitas ruang yang terbatas, sehingga tidak teridentifikasi pengubahan tatanan fisik secara signifikan pada kawasan Kampung Kreatif Dago Pojok. 


\section{DAFTAR PUSTAKA}

Altman, I. \& Low, S.M. (1992). Place Attachment: Human Behavior and Environment - Advances in Theory and Research. New York: Plenum Press.

Kustianingrum, Dwi. (2010). Tatanan Spasial Permukiman Tak Terencana Kampung Babakan Ciamis Kota Bandung. Jurnal Rekayasa LPPM Itenas. Vol XIV. No 4

Haryadi, Setiawan, B. 1995. Arsitektur Lingkungan dan Perilaku. Yogyakarta. Proyek Pengembangan Pusat Studi Lingkungan Direktorat Jendral Pendidikan Tinggi Departemen Pendidikan dan Kebudayaan Republik Indonesia

Landry, Charles. (2008). The Creative City: a Toolkit for Urban Innovators : Comedia

Lang, J. T. (1987). Creating architectural theory: the role of the behavioral sciences in environmental design. New York:Van Nostrand Reinhold Co..

Laurens, Joyce Marcella. (2006). Arsitektur dan Perilaku Manusia. Jakarta: Grasindo

Kementerian Perindustrian. (2010). Pedoman Umum dan Petunjuk Teknis Pengembangan IKM melalui Pendekatan Satu Desa Satu Produk (One Kampong One Product-OVOP), Jakarta: Dirjen IKM Kementerian Perindustrian.

Norberg Schulz, C. (1984). The Concept of Dwelling, On The Way to Figurative Architecture, New York: Electa/Rizolly

Widjaja, Pele. (2013). Kampung-Kota Bandung. Yogyakarta: Graha Ilmu.

Yunus, Hadi Sabari. (2001) .Struktur Tata Ruang Kota. Yogyakarta: Pustaka Pelajar.

Zahn, Markus, (1999). Perancangan Kota Secara Terpadu : Teori Perancangan Kota dan Penerapannya, Yogyakarta, Kanisius 